\title{
Determination of TGF $\beta$ I protein level in human primary breast cancers and its relationship with survival
}

\author{
S Desruisseau', J Palmari', C Giusti ${ }^{2,3}$, S Romain', P-M Martin' and Y Berthois*,2 \\ 'Assistance Publique-Hopitaux de Marseille, Laboratoire de Transfert en Oncologie Biologique, Faculté de Médecine Secteur Nord, 13916 Marseille \\ Cedex 20, France; 'INSERM EMI 0359, Laboratoire de Cancérologie Expérimentale, IFR Jean-Roche, Faculté de Médecine Secteur Nord, Bd Pierre \\ Dramard, 13916 Marseille Cedex 20, France
}

Transforming growth factor-beta $(\mathrm{TGF} \beta) \mathrm{I}$ is thought to be implicated in breast cancer progression. However, data about the influence of TGF $\beta$ I on breast cancer development are conflicting. To clarify the clinical relevance of TGF $\beta$ I, TGF $\beta$ | protein level has been measured by enzyme-immoassay in 193 breast tumour samples. We found that $94.3 \%$ of patients expressed TGF $\beta$ I with a range of $0-684 \mathrm{pg} \mathrm{mg}^{-1}$ protein. In the overall population, an increase of tumoral TGF $\beta$ I was observed in premenopausal patients when compared to postmenopausal subgroup $(P=0.0006)$. When patients were subdivided according to nodal status, TGF $\beta \mid$ was correlated to type-I plasminogen activator inhibitor in the node-negative subgroup $(P=0.040)$. Multivariate analysis revealed that, after lymph node status $(P=0.0002)$ and urokinase-type plasminogen activator $(P=0.004)$, TGF $\beta$ I was an independent prognostic marker for DFS $(P=0.005)$ in the overall population. In the node-negative population, TGF $\beta$ I was the prominent prognostic factor $(P=0.010)$. In the same population, Kaplan-Meier curves demonstrated that high TGF $\beta$ I level was correlated with a shorter diseasefree survival $(P=0.020)$. These data suggest that the measurement of tumoral TGF $\beta$ I protein level, especially for node-negative patients, might help to identify a high-risk population early in tumour progression.

British Journal of Cancer (2006) 94, 239-246. doi:I0.1038/sj.bjc.6602920 www.bjcancer.com

Published online 10 January 2006

(c) 2006 Cancer Research UK

Keywords: transforming growth factor-betal; breast cancer; survival

Transforming growth factor-beta (TGF $\beta$ ) belongs to a superfamily of secreted polypeptides, which regulate cell proliferation, differentiation, motility and apoptosis in a variety of different cell types (Roberts and Sporn, 1990). Three TGF $\beta$ isoforms 1-3 are ubiquitously expressed and have been detected in humans and other mammals. TGF $\beta 1$ have been associated with both normal mammary gland development and breast carcinogenesis (Wakefield et al, 2000). Thus, in vivo, TGF $\beta 1$ appears to regulate normal ductal and alveolar development in the mammary gland (Jhappan et al, 1993). Moreover, TGF $\beta 1$ probably mediates the massive cell death and restructuring that takes place during postlactational involution of the mammary gland (Strange et al, 1992). Besides these physiological functions, there is considerable evidence that TGF $\beta 1$ is implicated in several aspects of breast cancer onset and progression (Wakefield et al, 2000). A commonly held view is that TGF $\beta 1$ prohibits tumour cell proliferation because TGF $\beta 1$ is a potent growth inhibitor for nearly all epithelia in vitro (Roberts and Sporn, 1990). Moreover, TGF $\beta 1$ can induce

\footnotetext{
*Correspondence: Dr Y Berthois;

E-mail: berthois.y@jean-roche.univ-mrs.fr

Grant sponsor: Ministère Français de la Santé (1995), on behalf of $P$ Bonnier, JM Brandone, C Bressac, JM Blanc, L Cals, C Charpin, J Del Grande, J Guidon, A Lachard, P Nouyrigat, L Piana, and M Pizzi-Anselme. ${ }^{3} \mathrm{CG}$ was supported by fellowship from 'Association pour la Recherche contre le Cancer' and 'Ligue Nationale contre le Cancer'.

Received 26 July 2005; revised 2 November 2005; accepted 25 November 2005; published online 10 January 2006
}

apoptosis, a process associated with tumour suppression, promote replicative senescence and exhibit negative regulation of angiogenesis (Alexander and Moses, 1995; Schwarte-Waldhoff et al, 2000; Perlman et al, 2001). Consistent with a tumoursuppressor role, transgenic mouse models have bring evidence that TGF $\beta 1$ is able to protect against mammary tumour development in vivo, because either the suppression of TGF $\beta 1$ or the inactivation of the TGF $\beta$ signalling pathway results in loss of tumour prohibition and promotes carcinogenesis (Pierce et al, 1995; Bottinger et al, 1997). On the other hand, virally transformed tumorigenic mammary epithelial cell lines as well as most of the cell lines derived from invasive human breast carcinomas are resistant to the antiproliferative effects of TGF $\beta 1$ in vitro and do not respond to treatment with TGF $\beta 1$ in vivo. In a number of cases, this is attributable to inhibiting mutations in either TGF $\beta$ type I or II receptors (Chen et al, 1998; Gobbi et al, 2000) or deregulation of the downstream signalling cascade (Xie et al, 2002).

In addition, there is increasing evidence that after cells lose their sensitivity to TGF $\beta 1$-mediated growth inhibition, autocrine TGF $\beta$ signalling may promote tumorigenesis. Consistent with a prooncogenic role for TGF $\beta 1$ in late-stage cancer, elevated levels of TGF $\beta 1$ are often observed in advanced carcinomas, and have been correlated with increased tumour invasiveness and disease progression in a variety of tumours such as malignant melanoma (Moretti et al, 1999) and colonic (Tsushima et al, 1996), ovarian (Bristow et al, 1999), and prostatic (Shariat et al, 2004) cancers. This suggests that secreting higher levels of TGF $\beta 1$ may provide an advantage to tumour cells. Pro-oncogenic effects include direct 
effects of TGF $\beta 1$ on tumoral cells, such as the stimulation of invasion and motility (Oft et al, 1996). Tumour TGF $\beta 1$ may also indirectly promote cancer progression by promoting tumour vascularisation (Oh et al, 2000) and inhibiting mechanisms of immune surveillance (Letterio and Roberts, 1998).

In breast cancer, a number of studies have been engaged to evaluate the potential prognostic value of TGF $\beta 1$. In most of these studies, tumoral TGF $\beta 1$ expression has been examined either by immuno-histochemical assay or by Northern blot analysis. Although several groups demonstrated that increased TGF $\beta 1$ was associated with more aggressive tumour behavior and poorer survival (Gorsch et al, 1992; Dalal et al, 1993; Walker et al, 1994), other authors reported the absence of correlation between disease progression and TGF $\beta 1$ immunostaining or mRNA level (Dublin et al, 1993; Ghellal et al, 2000). Furthermore, a few number of studies demonstrated that TGF $\beta 1$ was related to favorable outcome for patients with breast cancers (Murray et al, 1993; Kesari et al, 1999).

To date, quantitative determination of TGF $\beta 1$ protein level has been performed exclusively in plasma of breast cancer patients. While some studies failed to reveal any change in plasma TGF $\beta$ value in patients with breast cancer (Wakefield et al, 1995; Lebrecht et al, 2004), other reports demonstrate that patients with more advanced tumours have higher serum levels of TGF $\beta 1$ (Kong et al, 1995; Ivanovic et al, 2003), suggesting that serum TGF $\beta 1$ may reflect the severity of invasive breast cancer. However, these late studies have been performed on a small cohort of patients and potential prognostic value of TGF $\beta 1$ has not been clearly determined. To clarify the relevance of TGF $\beta 1$ as a prognostic marker in human breast cancer, we quantified TGF $\beta 1$ protein level in 193 breast tissue specimens. The association between TGF $\beta 1$ and the usual histological and biological parameters previously validated was examined. The prognostic relevance of TGF $\beta 1$ for disease-free (DFS) and overall survival (OS) was studied for all patients by Cox multivariable analysis including the traditional prognostic markers.

\section{MATERIALS AND METHODS}

\section{Patient population}

This study involved 193 patients diagnosed and treated in Assistance Publique of Marseille (France) between early 1987 and late 1992. These patients were previously included in a retrospective multicenter study (Romain et al, 2000). Patients were selected according to the following criteria: (1) primary unilateral breast tumour; (2) previously untreated, no evidence of metastatic disease or any other malignancy at the time of diagnosis; (3) T1T2, N0N1 status according to UICC criteria; (4) $<75$ years old; and (5) surgery as the first treatment.

The patients were 29-74 years old at diagnosis, with a median age of 57 years. In total, $37.3 \%$ of patients were premenopausal. A total of 83 patients presented a tumour size $\leqslant 2 \mathrm{~cm} ; 48.7 \%$ of patients were node-negative $(\mathrm{N}-), 29.6 \%$ presented one to three axillary invaded nodes $(\mathrm{N}+)$ and $21.7 \%$ had more than three invaded nodes $(\mathrm{N}++)$. Among the 193 tumours graded according to Scarff, Bloom and Richardson classification (SBR), $25.5 \%$ were classified grade I, $52.8 \%$ were grade II, and $21.7 \%$ were grade III. Ductal carcinomas were diagnosed in $75 \%$ of patients, and invasive lobular carcinomas in $25 \%$ of patients.

The primary treatment was tumorectomy or quadrantectomy $(92 \%)$ or modified radical mastectomy (8\%) with axillary dissection, followed by radiotherapy in $98 \%$ of cases. Among the 121 postmenopausal patients, 21 received no adjuvant treatment whereas 33 received hormone therapy, 33 were treated with chemotherapy, and 34 received both treatments. Among the 72 premenopausal patients, 36 received no adjuvant therapy and 36 were treated as follow: 10 with chemotherapy, 22 with hormone therapy and four patients with both treatments. The median follow-up was 94 months (range, 1-140). At the cutoff date of this study, 16 local recurrences, 42 metastasis and 28 deaths had been recorded. Tumour samples and clinical informations were obtained under Institutional Clinical Board approval.

\section{Preparation of tumour tissue extracts and ER and PR assays}

Tumour tissues were stored in liquid nitrogen and routinely assayed for estrogen (ER) and progesterone receptors (PR) levels, according the recommendations of the European Organization for Research and Treatment of Cancer (EORTC), as previously described (Foekens et al, 1989). Tumour tissues were pulverised in the frozen state with a microdismembrator (Braun, Melsungen, Germany) as recommended by the EORTC. The resulting powder was suspended in buffer containing $10 \mathrm{~mm}$ Tris- $\mathrm{HCl} \mathrm{pH} \mathrm{7.4,} 1.5 \mathrm{~mm}$ EDTA, $10 \mathrm{~mm} \mathrm{Na} \mathrm{MoO}_{4}, 0.5 \mathrm{~mm}$ DTT and $10 \%$ glycerol. The suspension was centrifuged for $60 \mathrm{~min}$ at $105000 \mathrm{~g}$ at $4^{\circ} \mathrm{C}$. The high-speed supernatants (cytosols) were collected and stored in liquid nitrogen. For all samples, cytosolic protein concentration was determined using BCA assay (Pierce Chemical, Rockford, IL, USA). ER and PR levels were determined by enzyme immunoassay as described previously (Foekens et al, 1989). To assess the between-assay variations, in each series of tests an aliquot of a pooled breast cancer cytosol sample was analyzed.

The remaining cytosols were frozen and stored in liquid nitrogen until used for the determination of thymidine kinase (TK) enzyme activity, urokinase-type plasminogen activator (uPA), type-1 plasminogen activator inhibitor (PAi-1), and TGF $\beta 1$.

\section{TK, uPA and PAi-1 assays}

TK enzyme activity was measured using the Prolifigen TK Radioenzymatic Assay (Sangtec Medical, Bromma, Sweden), with the modifications recommended by the EORTC Receptors and Biomarkers Study Group (Foekens et al, 2001).

uPA levels were measured with the Immunobind ${ }^{\mathbb{R}}$ uPA ELISA kit and PAi-1 levels by the Immunobind ${ }^{\mathbb{R}}$ PAil ELISA kit (American Diagnostic, Greenwich, CT, USA), according to the instructions of the manufacturer. Inactive and active forms of uPA are all recognised by the uPA ELISA kit, as is receptor-bound uPA and uPA complexed with PAi-1 and PAi-2. PAi-1 ELISA detects latent and active forms of human PAi-1 and PAi-1 complexes. The assay is insensitive to PAi-2.

\section{TGF $\beta 1$ measurement}

TGF $\beta 1$ levels in breast tumour cytosols were measured by ELISA. This assay used monoclonal antibody (R\&D Systems, UK) as capture antibody and biotinylated polyclonal antibody (R\&D Systems, UK) as detection antibody. The assay specifically measures active TGF $\beta 1$ forms. To measure total TGF $\beta 1$ present in tumour samples, biologically latent TGF $\beta 1$ was activated by acid-treatment. For this purpose, cytosols were diluted with four volumes of DPBS buffer $(2.7 \mathrm{~mm} \mathrm{KCl}, 137 \mathrm{~mm} \mathrm{NaCl}, 1.5 \mathrm{~mm}$ $\mathrm{KH}_{2} \mathrm{PO}_{4}, 3.2 \mathrm{mM} \mathrm{Na} \mathrm{HPO}_{4}, 1 \mathrm{~mm} \mathrm{CaCl}_{2}, 0.5 \mathrm{~mm} \mathrm{MgCl}_{2}, \mathrm{pH} 7.4$ ). Samples were then incubated for $15 \mathrm{~min}$ at room temperature in the presence of $0.02 \mathrm{vol}$ of $1 \mathrm{~N} \mathrm{HCl}$, then neutralised with equal volume of $1 \mathrm{~N} \mathrm{NaOH}$. ELISA analysis was performed in 96-well plates following the instructions of the manufacturer (R\&D Systems, UK). Recombinant human TGF $\beta 1$ (R\&D Systems, UK) was used as standard at $0-1000 \mathrm{pg} \mathrm{ml}^{-1}$. A preliminary evaluation was performed to assess the buffer compatibility and the parallelism of sample dilutions. The inter- and intra-assay 
$(n=10)$ CVs of a pool of tumour extracts with mean value of $134.1 \mathrm{pg}$ TGF $\beta 1$ per mg protein were 7.5 and $3.9 \%$ respectively.

\section{Statistical analysis}

The strength of the associations of TGF $\beta 1$ with other variables was tested with Spearman rank correlation. The associations of TGF $\beta 1$ (used as continuous variables) with other variables (used as grouping variables) were examined using Mann-Whitney $U$ test (two categories), or in the case of more than two ordered categories by Kruskal-Wallis test. Survival curves were generated using the method of Kaplan and Meier and the log-rank test for trend was used to examine survival data. For the univariate survival analysis, DFS time (the interval between date of surgery and primary failure defined as a locoregional and/or distant recurrence) and OS time (the interval between date of surgery and death by any cause) were used as follow-up parameters. $P$-values $\leqslant 0.05$ were considered as significant.

Cox multivariate regression analysis was used to evaluate the prognostic value of TGF $\beta 1$ in the overall or $\mathrm{N}+$ or $\mathrm{N}-$ populations. Multivariate analysis was performed with variables eliminated in a step-down fashion. Variables with a $P \leqslant 0.05$ were retained in the final multivariate models. Hazard ratios (HR) derived from the estimated regression coefficients, are presented with their 95\% confidence intervals (CI).

Variables were categorised as follows: age (50 or younger, and older than 50), pathological tumour size ( $\leqslant 20 \mathrm{~mm}$ or $>20 \mathrm{~mm}$ ), menopausal status (premenopausal $v s$ postmenopausal), pathological nodal status $(\mathrm{N}-$, none; $\mathrm{N}+, 1$ to $3 ; \mathrm{N}++$, more than 3 ), histologic grade (SBR grade I, II or III), and histologic type (ductal $v s$ lobular).

In regard to the variations of ER levels observed in premenopausal vs postmenopausal patients (39), all tumours were considered to be estrogen receptor-negative (ER-) if ER values $<15 \mathrm{fmol} \mathrm{mg}^{-1}$ protein; for the premenopausal population, tumours with ER $15-205 \mathrm{fmol} \mathrm{mg}^{-1}$ protein (75th percentile) were classified ER +, whereas tumours of postmenopausal patients were considered as ER + when ER level was $15-377 \mathrm{fmol} \mathrm{mg}^{-1}$ protein (75th percentile). In both pre- and post-menopausal populations, $\mathrm{ER}++$ represents tumours with ER values exceeding the 75 th percentile. In all cases, the tumours were considered to be PRpositive if values exceeded $20 \mathrm{fmol} \mathrm{mg}^{-1}$ protein. For all others biological parameters, cutpoints corresponded to the 25th and 75th percentiles of the distribution (see Table 1).

\section{RESULTS}

\section{Clinicopathological characteristics}

The clinicopathological characteristics of the patients are presented in Table 1. Patients were characterised according to their age, hormonal (menopausal) and steroid receptor status, tumour grade according the SBR grading system, histology and size of the tumour, and the axillary nodal status.

\section{Biological characteristics of the breast cancer samples analyzed}

The distribution of biological factors in breast cancer samples are listed in Table 2. A wide inter-patient variability in the levels of all the parameters measured could be observed. ER, PR and TK levels were previously determined in our laboratory and integrated elsewhere in other published study (Romain et al, 1995, 2000). uPA and PAi-1 levels ranged from 0.01 to $1.39 \mathrm{ng} \mathrm{mg}^{-1}$ protein (median, 0.20 ) and from 0.27 to $54 \mathrm{ng} \mathrm{mg}^{-1}$ protein (median, 6.0), respectively. TGF $\beta 1$ was detectable in $94.3 \%$ of samples and its concentration ranged from 0 to $684 \mathrm{pg} \mathrm{mg}^{-1}$ protein, with a median at $86.7 \mathrm{pg} \mathrm{mg}^{-1}$ protein.
Table I Patient characteristics

\begin{tabular}{llcc}
\hline Feature & Category & No. of patients & Percentage \\
\hline Total population & & 193 & \\
Age (years) & $\leqslant 50$ & 62 & 32.1 \\
& $>50$ & 131 & 67.9 \\
Hormonal status & Premenopausal & 72 & 37.3 \\
& Menopausal & 121 & 62.7 \\
Receptor status & a & & \\
& ER- PR- & 21 & 10.9 \\
& ER- PR+ & 7 & 3.6 \\
& ER+ PR- & 39 & 20.2 \\
Histology & ER+ PR+ & 126 & 65.3 \\
& & 145 & 75.1 \\
Tumour size & Invasive duct & 48 & 24.9 \\
& Invasive lobular & 83 & 43.0 \\
SBR grade & TI & 110 & 57.0 \\
& T2 & 49 & 25.5 \\
& I & 102 & 52.8 \\
Nodal status & III & 42 & 21.7 \\
& $\mathrm{~N}-$ & 94 & 48.7 \\
& $\mathrm{~N}+$ & 57 & 29.6 \\
& $\mathrm{~N}++$ & 42 & 21.7 \\
\hline
\end{tabular}

aThe subgroups ER+ include the patients with $\mathrm{ER}+$ and $\mathrm{ER}++\left(\mathrm{ER}>15 \mathrm{fmolmg} \mathrm{m}^{-}\right.$ protein), as defined in Materials and Methods section.

Table 2 Biological characteristics of the breast cancer population

\begin{tabular}{|c|c|c|c|c|c|}
\hline Variables & Range & Mean $(I C)^{a}$ & Q25 & Q50 & Q75 \\
\hline \multicolumn{6}{|l|}{ ER (fmol $\mathrm{mg}^{-1}$ protein) } \\
\hline Overall population & $0-654$ & $197(23.9)$ & 33 & 149 & 325 \\
\hline Premenopausal & $1-455$ & $122(26.8)$ & 22 & 87 & 205 \\
\hline Postmenopausal & $0-654$ & $218(22.4)$ & 67 & 254 & 377 \\
\hline PR (fmol $\mathrm{mg}^{-1}$ protein) & $0-1000$ & $156(26.3)$ & 8.7 & 67 & 274 \\
\hline TK (mU mg ${ }^{-1}$ protein) & $4-2804$ & $349(66.9)$ & 70 & 138 & 388 \\
\hline uPA (ng mg ${ }^{-1}$ protein) & $0.01-1.39$ & $0.28(0.03)$ & 0.11 & 0.20 & 0.38 \\
\hline PAi-I (ng mg ${ }^{-1}$ protein) & $0.27-54$ & $8.73(1.19)$ & 3.7 & 6.0 & 10 \\
\hline TGF $\beta \mid$ (pg mg- ${ }^{-1}$ protein) & $0-684$ & $121(16.6)$ & 42 & 86.7 & 148 \\
\hline
\end{tabular}

${ }^{\mathrm{a}} 95 \%$ confidence interval, $\mathrm{Cl}$.

\section{Relationships between TGF $\beta 1$ and clinicopathological and biological parameters}

When the correlation between TGF $\beta 1$ and each of the others parameters was examined in the overall population, no significant correlation could be observed between TGF $\beta 1$ and the biological and clinicopathological variables, except the hormonal status. Thus, premenopausal patients were found to express higher TGF $\beta 1$ levels than postmenopausal patients (114 vs $86 \mathrm{pg} \mathrm{mg}^{-1}$ protein, $P=0.0006$ ) (not shown). When patient population was subdivided according to pathological nodal status, TGF $\beta 1$ remained correlated to the hormonal status in both node-negative $(P=0.012)$ and node-positive $(P=0.008)$ subgroups (Table 3$)$. Moreover, a positive association between TGF $\beta 1$ and PAi-1 $(P=0.040)$ was observed in the node-negative population.

\section{Prognostic relevance}

The impact of TGF $\beta 1$ on OS and DFS was determined in the overall population and node-negative/node-positive subsets. When 25th 
Table 3 Relationship between TGF $\beta \mid$ and biological and clinicopathological variables

\begin{tabular}{|c|c|c|c|c|c|}
\hline & \multicolumn{5}{|c|}{ Node-negative patients } \\
\hline & $n$ & Range & $\mathbf{Q}_{50}$ & $P$ & $\rho$ \\
\hline \multicolumn{6}{|l|}{ Hormonal status } \\
\hline Premenopausal & 35 & $8-567$ & 132 & & \\
\hline Postmenopausal & 59 & $0-349$ & 74 & 0.012 & -0.259 \\
\hline \multicolumn{6}{|l|}{ Tumour size } \\
\hline $\mathrm{TI}$ & 61 & $0-349$ & 74 & & \\
\hline $\mathrm{T} 2$ & 33 & $3-367$ & 91 & 0.725 & 0.036 \\
\hline \multicolumn{6}{|l|}{ SBR grade } \\
\hline $1^{\circ}$ & 30 & $3-349$ & 100 & & \\
\hline$\|$ & 48 & $0-367$ & 82 & & \\
\hline III & 16 & $3-337$ & 79 & 0.885 & 0.015 \\
\hline \multicolumn{6}{|l|}{$E R$} \\
\hline Negative & 17 & $17-259$ & 75 & & \\
\hline Low & 56 & $0-367$ & 85 & & \\
\hline High & 21 & $9-349$ & 117 & 0.906 & 0.094 \\
\hline \multicolumn{6}{|l|}{$P g R$} \\
\hline Negative & 30 & $3-341$ & 72 & & \\
\hline Positive & 64 & $0-349$ & 104 & 0.696 & 0.041 \\
\hline \multicolumn{6}{|l|}{ TK } \\
\hline Negative & 26 & $3-349$ & 102 & & \\
\hline Low & 50 & $0-337$ & 69 & & \\
\hline High & 18 & $15-684$ & 132 & 0.293 & 0.108 \\
\hline \multicolumn{6}{|l|}{ UPA } \\
\hline Negative & 28 & $0-303$ & 72 & & \\
\hline Low & 42 & $7-349$ & 107 & & \\
\hline High & 24 & $4-337$ & 79 & 0.380 & 0.091 \\
\hline \multicolumn{6}{|l|}{ PAl-I } \\
\hline Negative & 26 & $0-167$ & 72 & & \\
\hline Now & 47 & $3-366$ & 81 & & \\
\hline \multirow[t]{3}{*}{ High } & 21 & $3-684$ & 149 & 0.040 & 0.211 \\
\hline & \multicolumn{5}{|c|}{ Node-positive patients } \\
\hline & $n$ & Range & $\mathbf{Q}_{50}$ & $P$ & $\rho$ \\
\hline \multicolumn{6}{|l|}{ Hormonal status } \\
\hline Premenopausal & 37 & $13-684$ & 120 & & \\
\hline Postmenopausal & 62 & $2-405$ & 71 & 0.008 & -0.265 \\
\hline \multicolumn{6}{|l|}{ Tumour size } \\
\hline $\mathrm{TI}$ & 22 & $5-679$ & 88 & & \\
\hline $\mathrm{T} 2$ & 77 & $2-684$ & 76 & 0.943 & -0.007 \\
\hline \multicolumn{6}{|l|}{ SBR grade } \\
\hline I & 19 & $4-346$ & 76 & & \\
\hline$\|$ & 54 & $2-643$ & 98 & & \\
\hline III & 26 & $2-684$ & 62 & 0.680 & -0.041 \\
\hline \multicolumn{6}{|l|}{$E R$} \\
\hline Negative & 10 & $14-433$ & 107 & & \\
\hline Low & 62 & $3-643$ & 83 & & \\
\hline High & 27 & $3-684$ & 89 & 0.728 & 0.035 \\
\hline \multicolumn{6}{|l|}{$\operatorname{PgR}$} \\
\hline Negative & 32 & $3-684$ & 101 & & \\
\hline Positive & 67 & $2-678$ & 87 & 0.929 & 0.009 \\
\hline \multicolumn{6}{|l|}{ TK } \\
\hline Negative & 20 & $3-257$ & 83 & & \\
\hline Low & 42 & $2-387$ & 107 & & \\
\hline High & 37 & $10-325$ & 82 & 0.749 & 0.032 \\
\hline
\end{tabular}

Table 3 (Continued)

\begin{tabular}{llllll}
\hline & \multicolumn{5}{c}{ Node-positive patients } \\
\cline { 2 - 5 } & $\boldsymbol{n}$ & Range & $\mathbf{Q}_{\mathbf{5 0}}$ & $\boldsymbol{P}$ & $\boldsymbol{\rho}$ \\
\hline uPA & & & & & \\
Negative & 17 & $3-348$ & 87 & & -0.027 \\
Low & 56 & $2-684$ & 96 & & \\
High & 26 & $6-151$ & 90 & 0.793 & \\
PAl-I & & & & & \\
Negative & 21 & $3-643$ & 82 & & -0.003 \\
Now & 50 & $4-341$ & 89 & & \\
High & 28 & $6-676$ & 100 & 0.977 & \\
\hline
\end{tabular}

$n=$ number of patients; $Q_{50}$, median values.

and 75th percentiles of the distribution were used as cutoff values, TGF $\beta 1$ appeared significant $(P=0.020)$ for DFS in the overall population (Figure 1A). The 10-year probability of DFS was $86.4 \%$ for patients with low TGF $\beta 1$ levels ( $<42 \mathrm{pg} \mathrm{mg}^{-1}$ protein), $72 \%$ for the intermediate group $(42-148 \mathrm{pg}$ TGF $\beta 1 / \mathrm{mg}$ protein) and $61 \%$ for patients with TGF $\beta 1 \geqslant 148 \mathrm{pg} \mathrm{mg}^{-1}$ protein. The patients were then dichotomised according to their nodal status. While TGF $\beta 1$ was found to have no significant impact on DFS in the nodepositive subgroup (not shown), high TGF $\beta 1$ levels were significantly associated with poor DFS in the node-negative population $(P=0.02)$ (Figure 1B). Thus, among the node-negative patients with low TGF $\beta 1$ level, no relapse (DFS $=100 \%)$ were observed, whereas 17 and 38\% relapses were observed for patients with intermediate and high TGF $\beta 1$ expression levels, respectively. Unlikely, the level of TGF $\beta 1$ had no impact on OS, neither in the overall population nor in the node-positive/node-negative groups (not shown).

A Cox multivariate analysis was performed to evaluate whether TGF $\beta 1$ might significantly add to the contribution of the traditional prognostic factors. A significance level of $5 \%$ in the univariate analysis was chosen as the criterion for entering variables (SBR grade, nodal status, ER, uPA, PAi-1, TK and TGF $\beta 1$ ) (not shown). The analysis was conducted in the overall population and node-negative/node-positive subgroups (Table 4). The analysis performed for OS revealed nodal status $(P=0.0003)$ and SBR grade $(P=0.0008)$ as independent parameters in the overall population. The prominent predictor for OS was SBR grade $(P=0.004)$ and ER $(P=0.020)$ in the node-positive population, and uPA $(P=0.010)$ in the node-negative subgroup. In addition of nodal status $(P=0.0002)$ and uPA $(P=0.004)$, TGF $\beta 1$ was independently associated to poor DFS in the overall population $(P=0.005)$. Whereas PAi-1 appeared as the prominent independent predictor for the node-positive patients $(P=0.019)$, the parameter associated with DFS in the population without nodeinfiltration was TGF $\beta 1(P=0.010)$.

\section{DISCUSSION}

The reduced response to TGF $\beta$ in some tumour systems appears to involve multiple mechanisms, including loss of functional TGF- $\beta$ receptor proteins (Grady et al, 1999; Fukai et al, 2003). In addition, mutations of downstream TGF- $\beta$ signalling pathway genes have also been shown to result in a loss of responsiveness to TGF- $\beta 1$ (Wang et al, 2000; Maliekal et al, 2003). In contrast to many other tumours, structural lesions of TGF $\beta$ signal transducers appear to be rare in breast cancers (Chen et al, 1998; Xie et al, 2002; Jeruss et al, 2003). This suggests that, in a number of circumstances such as cell dedifferentiation, the normal function of TGF $\beta 1$ in breast epithelial cells might be abrogated on behalf of oncogenic function. 

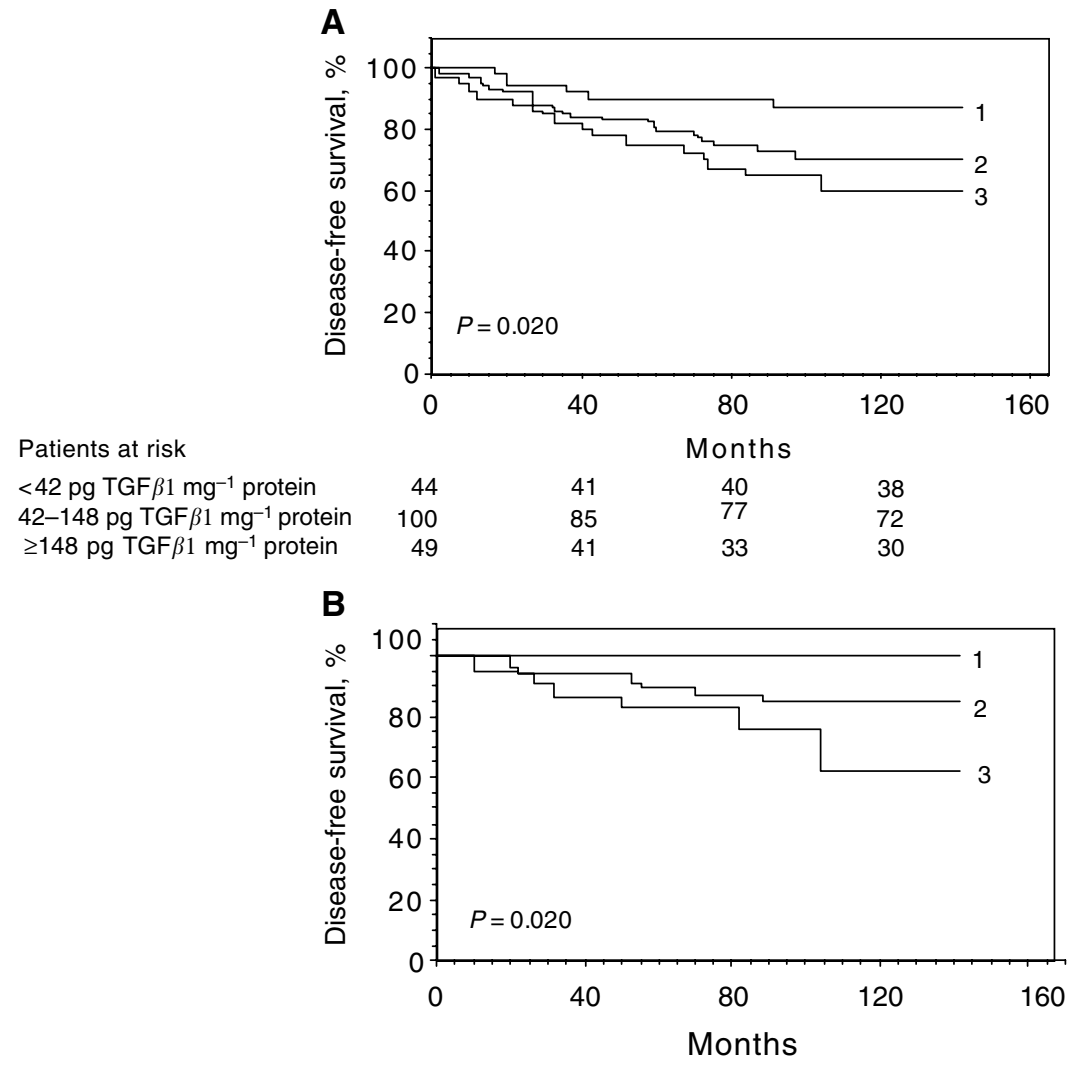

patients at risk

$\begin{array}{lllll}<42 \mathrm{pg} \text { TGF } \beta 1 \mathrm{mg}^{-1} \text { protein } & 24 & 24 & 24 & 24 \\ 42-148 \mathrm{pg} \text { TGF } \beta 1 \mathrm{mg}^{-1} \text { protein } & 46 & 44 & 40 & 38 \\ \geq 148 \mathrm{pg} \text { TGF } \beta 1 \mathrm{mg}^{-1} \text { protein } & 24 & 21 & 19 & 15\end{array}$

Figure I The probability of DFS for overall $(\mathbf{A})$ and node-negative (B) populations according to TGF $\beta$ | levels. I, negative (TGF $\beta \mid<42$ pg mg ${ }^{-1}$ protein); 2, low (42 $\mathrm{pg} \mathrm{mg}^{-1}$ protein $\leqslant \mathrm{TGF} \beta|<| 48 \mathrm{pg} \mathrm{mg}^{-1}$ protein); 3 , high (TGF $\beta|\geqslant| 48 \mathrm{pg} \mathrm{mg}^{-1}$ protein).

Whereas TGF $\beta 1$ seems to be confirmed as a marker of bad prognostic in a number of human tumours such as colorectal (Tsushima et al, 1996; Picon et al, 1998) and prostatic (Ivanovic et al, 1995; Shariat et al, 2004) cancers, the impact of TGF $\beta 1$ on the progression of breast cancer remains uncertain. As for carcinomas in other organs, TGF $\beta 1$ expression is often increased locally and systemically in advanced breast cancers, particularly at the leading invasive edge of the tumour and in metastasis (Dalal et al, 1993; Walker et al, 1994; Chakravarthy et al, 1999). Nevertheless, whereas the elevated expression of TGF $\beta 1$ is described to associate with disease progression in a number of studies (Gorsch et al, 1992; Dalal et al, 1993; Walker et al, 1994), others studies failed to reveal diagnostic or predictive value of TGF $\beta 1$ for breast cancer patients (Dublin et al, 1993; Murray et al, 1993; Kesari et al, 1999; Ghellal et al, 2000).

It is notable that, except when measured in plasma, most of the authors employed semiquantitative immunohistochemical staining to evaluate TGF $\beta 1$ protein level in breast samples. In this study, we have measured for the first time the level of TGF $\beta 1$ protein in breast tumour samples by ELISA, in order to examine potent correlations with clinical features. Using this assay, we found $94.3 \%$ of patients expressing TGF $\beta 1$ with a range of $0-684 \mathrm{pg} \mathrm{mg}^{-1}$ protein and a median value of $86.7 \mathrm{pg} \mathrm{mg}^{-1}$ of protein.

In agreement with a number of previous studies, we show in the overall population that TGF $\beta 1$ was correlated only with menopausal status. Thus, a moderate but significant increase of tumoral TGF $\beta 1$ level was observed in premenopausal patients when compared to postmenopausal subgroup $(P=0.0006)$. These data are in apparent opposition with some published studies, indicating that estradiol decreased the production of TGF $\beta 1$ by breast cancer epithelial cells in vitro (Knabbe et al, 1987; Philips and McFadden, 2004). Nevertheless, the diminution of TGF $\beta 1$ in postmenopausal patients might reflect adaptability process of tumoral cells to the profound hormonal modifications, which occur during menopause.

The increased expression of uPA has been reported to be associated with poor prognostic for patients with breast cancer (Duffy et al, 1998). Paradoxically, its inhibitor PAi-1 has also been described to contribute to the malignant phenotype of tumour cells (Look et al, 2002; Schrohl et al, 2004). Thus, PAi-1 might promote the development of tumoral angiogenesis through the stabilisation and maturation of new vessels (Bajou et al, 2004). Interestingly, TGF $\beta 1$ was also found to be positively correlated to PAi- 1 in the node-negative subgroup $(P=0.040)$. The activity of PAi-1 is tightly regulated on the transcriptional level, and TGF $\beta 1$ is the major regulator of PAi- 1 expression and in turn of local PAi-1 activity (Westerhausen et al, 1991). Thus, in the node-negative population, the upregulation of PAi- 1 by TGF $\beta 1$ might constitute an early event that promotes further progression of breast tumours. This is in agreement with our data indicating that TGF $\beta 1$ is an indicator of bad prognostic for breast cancer patients. Thus, multivariate analysis revealed that, after lymph node status $(P=0.0002)$ and uPA $(P=0.004)$, TGF $\beta 1$ was an independent prognostic marker for DFS $(P=0.005)$ in the overall population. Furthermore, TGF $\beta 1$ remained the prominent prognostic factor in the node-negative population $(P=0.010)$. In this late population, Kaplan-Meier 
Table 4 Cox multivariate analysis of OS and DFS, in overall population $(n=193)$, and in node-positive $(n=99)$ and node-negative patients $(n=94)$

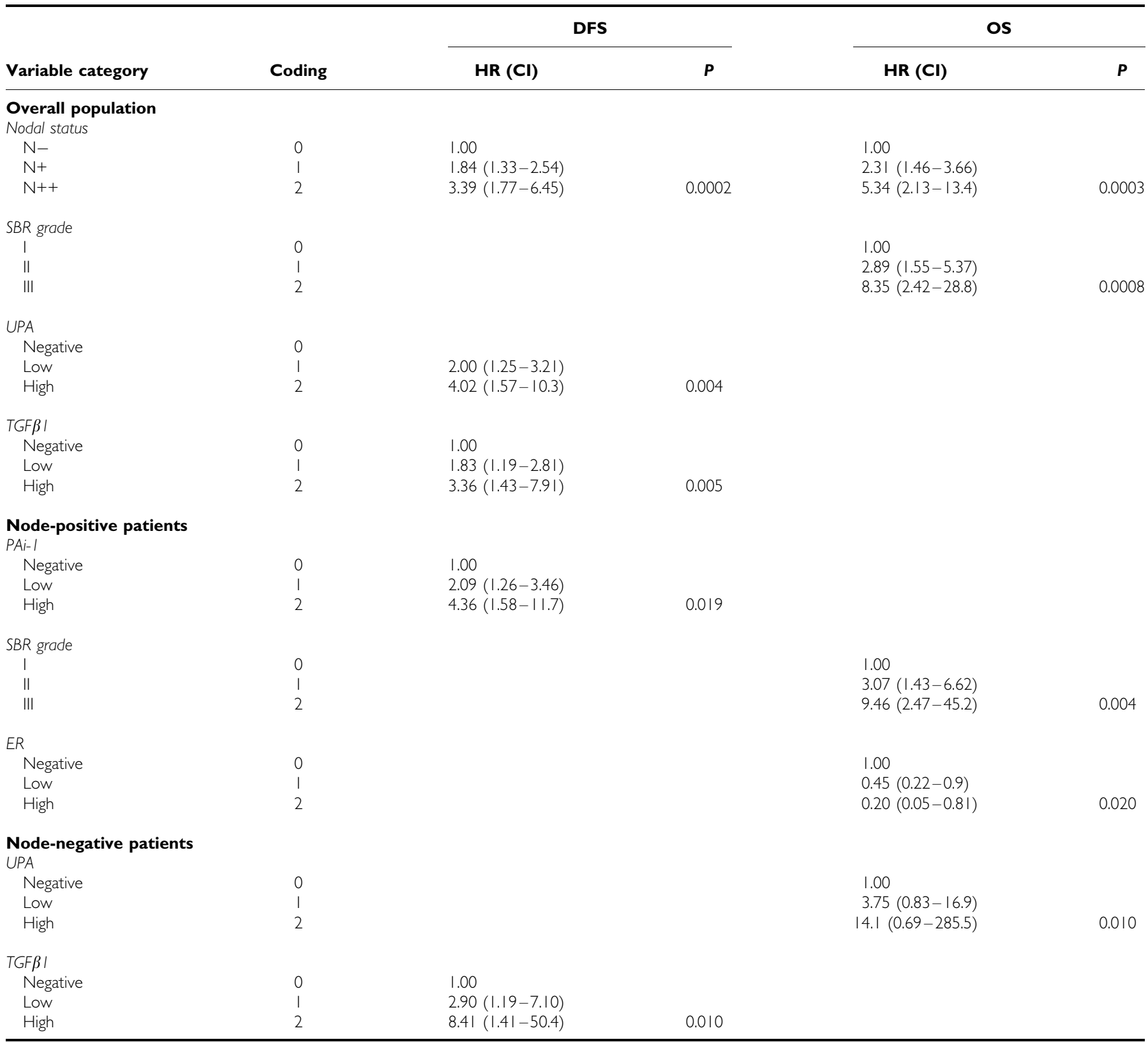

Candidate variables in the Cox model are listed in Results. HR, hazard ratio; $\mathrm{Cl}, 95 \%$ confidence interval.

curves further demonstrated that high level of TGF $\beta 1$ was correlated with a shorter disease-free survival $(P=0.020)$. Conversely, TGF $\beta$ was not a prognostic factor for OS in the nodenegative population. However, it has to be mentioned that at the cutoff date of the study, three deaths had been recorded in the node-negative subgroup. This is probably insufficient to distinguish a potential influence of TGF $\beta$ on overall survival, in this population. Whereas clinical studies in breast cancers have led to conflicting results, our data suggest that TGF $\beta 1$ has the potential to promote metastasis and recurrence for patients with breast carcinomas. It has to be noted that patients included in this study have not received modern chemotherapy, which could influence the outcomes. The fact that prognostic value of TGF $\beta 1$ was observed in node-negative population strongly suggests that TGF $\beta 1$ interferes at early stages of tumour progression, probably by making cell environment favorable for metastatic spread.
Although the lymph node status is one of the best prognostic factors in breast cancer, it is not sufficiently accurate to predict the clinical course of the disease. Indeed, $20-30 \%$ of node-negative breast cancer patients will experience disease recurrence and metastatic dissemination. Whereas numerous predictive factors have been characterised thus far, early prognostic markers that interfere at the beginning of tumour progression are scarce. The prognostic significance of high TGF $\beta 1$ level on DFS observed in node-negative breast cancer patients suggest that the determination of tumoral TGF $\beta 1$ status might help to identify a high-risk population early in tumour progression, for which a more appropriate therapy should be established. In this context, it appears fundamental to confirm the prognostic value of TGF $\beta$ in a large cohort of node-negative patients. Furthermore, as total TGF $\beta$ (active plus latent forms) has been measured in our study, it would be helpful to determine the respective role for latent and active $\operatorname{TGF} \beta$ as prognostic markers in breast cancers. 


\section{REFERENCES}

Alexander MG, Moses HL (1995) Transforming growth factor $\beta$ and cell cycle regulation. Cancer Res 55: $1452-1457$

Bajou K, Maillard C, Jost M, Lijnen RH, Gils A, Declerck P, Carmeliet P, Foidart JM, Noel A (2004) Host-derived plasminogen activator inhibitor1 (PAi-1) concentration is critical for in vivo tumoral angiogenesis and growth. Oncogene 23: 6986-6990

Bottinger EP, Jakubczak JL, Haines DC, Bagnall K, Wakefield LM (1997) Transgenic mice overexpressing a dominant-negative mutant type II transforming growth factor receptor show enhanced tumorigenesis in the mammary gland and lung in response to the carcinogen 7, 12-dimethylbenz-[a]-anthracene. Cancer Res 57: 5564-5570

Bristow RE, Baldwin R, Yamada SD, Korc M, Karlan BY (1999) Altered expression of transforming growth factor-beta ligands and receptors in primary and recurrent ovarian carcinoma. Cancer 85: 658-668

Chakravarthy D, Green AR, Green VL, Kerin MJ, Speirs V (1999) Expression and secretion of TGF-beta isoforms and expression of TGF-beta-receptors I, II and III in normal and neoplastic human breast. Int J Oncol 15: 187-194

Chen T, Carter D, Garrigue-Antar L, Reiss M (1998) Transforming growth factor- $\beta$ type I receptor kinase mutant associated with metastatic breast cancer. Cancer Res 58: $4805-4810$

Dalal BI, Keown PA, Greenberg AH (1993) Immunocytochemical localization of secreted transforming growth factor-beta 1 to the advancing edges of primary tumors and to lymph node matastases of human mammary carcinoma. Am J Pathol 143: 381 - 389

Dublin EA, Barnes DM, Wang DY, King RJ, Levison DA (1993) TGF alpha and TGF beta expression in mammary carcinomas. J Pathol 170: $15-22$

Duffy MJ, Duggan C, Mulcahy HE, McDermott EW, O’Higgins NJ (1998) Urokinase plasminogen activator: a prognostic marker in breast cancer including patients with axillary node-negative disease. Clin Chem 44: $1177-1183$

Foekens JA, Portengen $\mathrm{H}$, van Putten WL, Trapman AM, Reubi JC, Alexieva-Figusch J, Klijn JG (1989) Prognostic value of estrogen and progesterone receptors measured by enzyme immunoassays in human breast cancer tumor cytosol. Cancer Res 49: 5823-5828

Foekens JA, Romain S, Look MP, Martin PM, Klijn JGM (2001) Thymidine kinase and thymidylate synthase in advanced breast cancer: response to tamoxifen and chemotherapy. Cancer Res 61: 1421-1425

Fukai Y, Fukuchi M, Masuda N, Osawa H, Kato H, Nakajima T, Kuwano H (2003) Reduced expression of transforming growth factor-beta receptors is an unfavorable prognostic factor in human oesophageal squamous cell carcinoma. Int J Cancer 20: $161-166$

Ghellal A, Li C, Hayes M, Byrne G, Bundred N, Kumar S (2000) Prognostic significance of TGF beta 1 and TGF beta 3 in human breast carcinoma. Anticancer Res 20: 4413-4418

Gobbi H, Arteaga CL, Jensen RA, Simpson JF, Dupont WD, Olson SJ, Schuyler PA, Plummer Jr WD, Page DL (2000) Loss of expression of transforming growth factor $\beta$ type II receptor correlates with high tumour grade in human breast in-situ and invasive carcinomas. Histopathology (Oxford) 36: $168-177$

Gorsch SM, Memoli VA, Stukel TA, Golg LI, Arrick BA (1992) Immunohistochemical staining for transforming growth factor beta 1 associates with disease progression in human breast cancer. Cancer Res 52: $6949-6952$

Grady WM, Myeroff LL, Swinler SE, Rajput A, Thiagalingam S, Lutterbaugh JD, Neumann A, Brattain MG, Chang J, Kim SJ, Kinzler KW, Vogelstein B, Willson JK, Markowitz S (1999) Mutational inactivation of transforming growth factor $\beta$ receptor type II in microsatellite stable cancer colon. Cancer Res 59: $320-324$

Ivanovic V, Melman A, Davis-Joseph B, Valvic M, Geliebter J (1995) Elevated plasma levels of TGF-beta 1 in patients with invasive prostate cancer. Nat Med 1: 282-284

Ivanovic V, Todorovic-Rakovic N, Demajo M, Neskovic-Konstantinovic Z, Subota V, Ivanisevic-Milovanovic O, Nikolic-Vukosavljevic D (2003) Elevated plasma levels of transforming growth factor-beta 1 (TGF-beta 1) in patients with advanced breast cancer: association with disease progression. Eur J Cancer 39: 454-461

Jeruss JS, Sturgis CD, Rademaker AW, Woodruff TK (2003) Downregulation of activin, activin receptors, and smads in high-grade breast cancer. Cancer Res 63: 3783-3790

Jhappan C, Geiser AG, Kordon EC, Bagheri D, Hennighausen L, Roberts AB, Smith GH, Merlino G (1993) Targeting expression of a transforming growth factor $\beta 1$ transgene to the pregnant mammary gland inhibits alveolar development and lactation. EMBO J 12: 1835-1845

Kesari AL, Chellam VG, Mathew BS, Nair MK, Pillai MR (1999) Transforming growth factor beta related to extent of tumo angiogenesis but not apoptosis or proliferation in breast carcinoma. Breast Cancer 25: $29-36$

Knabbe C, Lippman ME, Wakefield LM, Flanders KC, Kasid A, Derynck R, Dickson RB (1987) Evidence that transforming growth factor-beta is a hormonally regulated negative growth factor in human breast cancer cells. Cell 48: $417-428$

Kong FM, Anscher MS, Murase T, Abbott BD, Iglehart JD, Jirtle RL (1995) Elevated plasma transforming growth factor-beta 1 levels in breast cancer patients decrease after surgical removal of the tumor. Ann Surg 222: $155-162$

Lebrecht A, Grimm C, Euller G, Ludwig E, Ulbrich E, Lantzsch T, Hefler L, Koelbl H (2004) Transforming growth factor beta 1 serum levels in patients with preinvasive and invasive lesions of the breast. Int J Biol Markers 19: $236-239$

Letterio JJ, Roberts AB (1998) Regulation of immune responses by TGF $\beta$. Annu Rev Immunol 16: 137-161

Look MP, van Putten WL, Duffy MJ, Harbeck N, Christensen IJ, Thomssen C, Kates R, Spyratos F, Ferno M, Eppenberger-Castori S, Sweep CG, Ulm K, Peyrat JP, Martin PM, Magdelenat H, Brunner N, Duggan C, Lisboa BW, Bendahl PO, Quillien V, Daver A, Ricolleau G, Meijer-van Gelder ME, Manders P, Fiets WE, Blankenstein MA, Broet P, Romain S, Daxenbichler G, Windbichler G, Cufer T, Borstnar S, Kueng W, Beex LV, Klijn JG, O'Higgins N, Eppenberger U, Janicke F, Schmitt M, Foekens JA (2002) Pooled analysis of prognostic impact of urokinase-type plasminogen activator and its inhibitor PAI-1 in 8377 breast cancer patients. J Natl Cancer Inst 94: 116-128

Maliekal TT, Antony ML, Nair A, Paulmurugan R, Karunagaran D (2003) Loss of expression and mutations of Smad2 and Smad4 in human cervical cancer. Oncogene 22: 4889-4897

Moretti S, Pinzi C, Spallanzani A, Berti E, Chiarugi A, Mazzoli S, Fabiani M, Vallecchi C, Herlyn M (1999) Immunohistochemical evidence of cytokine networks during progression of human melanocytic lesions. Int J Cancer 20: $160-168$

Murray PA, Barrett-Lee P, Travers M, Luqmani Y, Powles T, Coombes RC (1993) The prognostic significance of transforming growth factors in human breast cancer. Br J Cancer 67: 1408-1412

Oft M, Peli J, Rudaz C, Schwarz H, Beug H, Reichmann E (1996) TGF-betal and Ha-Ras collaborate in modulating the phenotypic plasticity and invasiveness of epithelial tumor cells. Genes Dev 10: $2462-2477$

Oh SP, Seki T, Goss KA, Imamura T, Yi Y, Donahoe PK, Li L, Miyazono K, ten Dijke P, Kim S, Li E (2000) Activin receptor-like kinase 1 modulates transforming growth factor- $\beta 1$ signaling in the regulation of angiogenesis. Proc Natl Acad Sci USA 97: 2626-2631

Perlman R, Schiemann WP, Brooks MW, Lodish HF, Weinberg RA (2001) TGF- $\beta$-induced apoptosis is mediated by the adaptor protein DAXX that facilitates JNK activation. Nat Cell Biol 13: 708-714

Philips N, McFadden K (2004) Inhibition of transforming growth factorbeta and matrix metalloproteinases by estrogen and prolactin in breast cancer cells. Cancer Lett 206: $63-68$

Picon A, Gold LI, Wang J, Cohen A, Friedman E (1998) A subset of metastasis human colon cancers expresses elevated levels of transforming growth factor beta1. Cancer Epidemiol Biomarkers Prev 7: 497 - 504

Pierce Jr DF, Gorska AE, Chytil A, Meise KS, Page DL, Coffey Jr RJ, Moses HL (1995) Mammary tumor suppression by transforming growth factor $\beta 1$ transgene expression. Proc Natl Acad Sci USA 92: $4254-4258$

Roberts AB, Sporn MB (1990) The transforming growth factor- $\beta$ s. In Peptide Growth Factors and their Receptors, Part I Sprone MB, Roberts AB (eds). pp 419-472. Berlin: Springer-Verlag

Romain S, Lainé-Bidron C, Martin P-M, Magdelenat H (1995) Steroid receptor distribution in 47892 breast cancers. A collaborative study of 7 European laboratories. Eur J Cancer 31A: 411 - 417

Romain S, Spyratos F, Descotes F, Daver A, Rostaing-Puissant B, Bougnoux P, Colonna M, Bolla M, Martin PM (2000) Prognostic of DNAsynthesizing enzyme activities (thymidine kinase and thymidylate synthase) in $908 \mathrm{~T} 1-\mathrm{T} 2, \mathrm{~N} 0-\mathrm{N} 1, \mathrm{M} 0$ breast cancers: a retrospective multicenter study. Int J Cancer 87: $860-868$

Schrohl AS, Holten-Andersen MN, Peters HA, Look MP, Meijer-van Gelder ME, Klijn JG, Brunner N, Foekens JA (2004) Tumor tissue levels of tissue 
TGF $\beta I$ in breast cancers

$\mathrm{S}$ Desruisseau et al

inhibitor of metalloproteinase-1 as a prognostic marker in primary breast cancer. Clin Cancer Res 10: 2289-2298

Schwarte-Waldhoff I, Volpert OV, Bouck NP, Sipos B, Hahn SA, KleinScory S, Luttges J, Kloppel G, Graeven U, Eilert-Micus C, Hintelmann A, Schmiegel W (2000) Smad4/DPC4-mediated tumor suppression through suppression of angiogenesis. Proc Natl Acad Sci USA 97: 9624-9629

Shariat SF, Kattan MW, Traxel E, Andrews B, Zhu K, Wheeler TM, Slawin KM (2004) Association of pre- and postoperative plasma levels of transforming growth factor $\beta 1$ and interleukin 6 and its soluble receptor with prostate cancer progression. Clin Cancer Res 10: $1992-1999$

Strange R, Li F, Saurer S, Burkhardt A, Friis RR (1992) Apoptotic cell death and tissue remodelling during mouse mammary gland involution. Development 115: 49-58

Tsushima $\mathrm{H}$, Kawata $\mathrm{S}$, Tamura $\mathrm{S}$, Ito $\mathrm{N}$, Shirai $\mathrm{Y}$, Kiso $\mathrm{S}$, Imai $\mathrm{Y}$, Shimomukai H, Nomura Y, Matsuda Y, Matsuzawa Y (1996) High levels of transforming growth factor beta 1 in patients with colorectal cancer: association with disease progression. Gastroenterology 110: 375-382

Wakefield LM, Letterio JJ, Chen T, Danielpour D, Allison RS, Pai LH, Denicoff AM, Noone MH, Cowan KH, O’Shaughnessy JA (1995) Transforming growth factor-betal circulates in normal human plasma and is unchanged in advanced metastatic breast cancer. Clin Cancer Res 1: $129-136$

Wakefield LM, Piek E, Bottinger EP (2000) TGF- $\beta$ signaling in mammary gland development and tumorigenesis. J Mammary Gland Biol Neoplasia 6: $67-82$

Walker RA, Dearing SJ, Gallacher B (1994) Relationship of transforming growth factor beta 1 to extracellular matrix and stromal infiltrates in invasive breast carcinoma. Br J Cancer 69: 1160-1165

Wang D, Kanuma T, Mizunuma H, Takama F, Ibuki Y, Wake N, Mogi A, Shitara Y, Takenoshita S (2000) Analysis of specific gene mutations in the transforming growth factor- $\beta$ signal transduction pathway in human ovarian cancer. Cancer Res 60: 4507-4512

Westerhausen Jr DR, Hopkins WE, Billadello JJ (1991) Multiple transforming growth factor-beta-inducible elements regulate expression of the plasminogen activator inhibitor type-1 gene in Hep G2 cells. J Biol Chem 266: $1092-1100$

Xie W, Mertens JC, Reiss DJ, Rimm DL, Camp RL, Haffty BG, Reiss M (2002) Alterations of smad signaling in human breast carcinoma are associated with poor outcome. A tissue microarray study. Cancer Res 62: $497-505$ 